\title{
Continental mantle root deep analysis: a 1000-km-long cross section of the Archean Karelian-Kola-Kuloi megacraton (Finland, NW Russia)
}

\author{
Petri Peltonen, Marja Lehtonen and Hugh O'Brien \\ Geological Survey of Finland, POB 96, FI-02151 Espoo, Finland
}

\section{Introduction}

A 1000-km-long vertical cross section of the continental mantle underlying the Archaean KarelianKola-Kuloi "megacraton" has been compiled by utilising mantle xenolith and xenocryst data from nine kimberlite localities: Kaavi, Kuopio, Kuhmo, Lentiira, Kuusamo South and North (Karelia), Terskyi Bereg (Kola) and Zolotitsa and Kepino-Pachuga kimberlite fields at Zimnyi Bereg (Kuloi). Alhough this compilation is based on existing - largely published data (Peltonen et al., 1999; Peltonen et al., 2003; O'Brien et al., 2003; Lehtonen et al., 2004; Lehtonen, 2005; Peltonen \& Brugmann, 2006; Malkovets et al., 2007; Lehtonen \& O'Brien, in prep.; Lehtonen et al., this volume; Ustinov et al., this volume; Zozulya et al., this volume), it attempts to provide fresh synthesis of our current understanding on the stabilisation, reworking, metasomatism and diamond potential of continental mantle underlying this vast and apparently complex collage of Archean terrains.

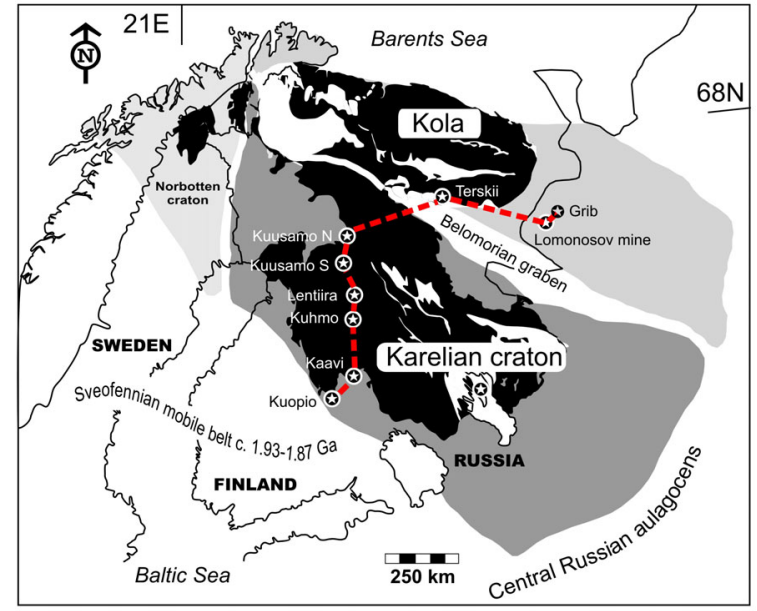

Fig. 1. Generalised geological map showing the extent of the four Archean subcratons, Kola, Karelia, Kuloi and Norbotten, which together make up the Archean of Fennoscandia. Black shading refers to the exposed Archean crust while grey shades denote the Archean crust that is covered by younger supracrustal rocks or that has been reworked during the Proterozoic. Locations of mantle xenocryst-bearing alkaline rocks used to construct the transect across the craton - are indicated by stars.

\section{Samples}

A significant amount of well-preserved mantle xenolith samples have been recovered only from the Kuopio and Kaavi kimberlites in Finland (Fig. 1). Rarely, xenoliths are also present in Kuhmo dikes, but xenoliths in Terskyi and Zimnyi Bereg pipes are always severely altered. Therefore, construction of our cross section is largely based on the composition and thermobarometry of pyrope and chrome diopside xenocrysts, i.e. "chemical tomography" of the SCLM at kimberlite localities, while xenoliths have provided invaluable information on the stabilisation age, physical and chemical properties, and diamond sources of the SCLM.
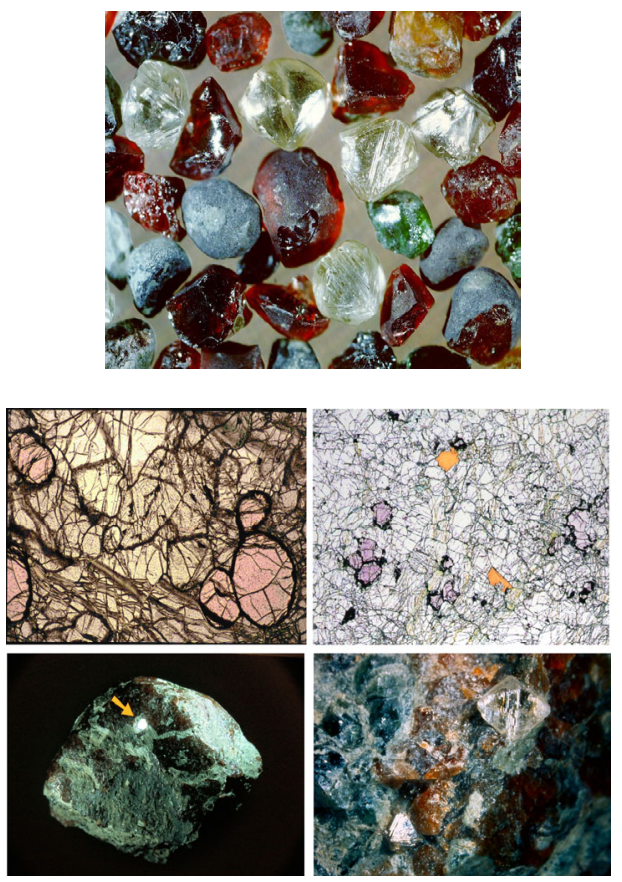

Fig. 2. Samples from Karelian SCLM: top row: xenocryst concentrate; middle row: microphotographs of garnet lherzolite, and garnet-spinel harzburgite xenoliths; bottom row: diamondiferous eclogite xenolith. 


\section{A 1000-km-long cross section}

Mantle-derived xenolith and xenocryst studies indicate that the subcontinental lithospheric mantle of the Karelian craton shows considerable variation from margin to core. At the craton margin, in the Kuopio and Kaavi area (Fig. 3), the mantle is stratified into at least three distinct layers. Shallow layer peridotites have "ultradepleted" compositions, and are interpreted to represent Proterozoic arc-type mantle thrusted under the craton margin. Xenoliths derived from the middle layer (at 110 - $180 \mathrm{~km}$ depth), which is the main source of harzburgitic garnets (G10) in Kaavi-Kuopio kimberlites, are characterised by an unradiogenic Os isotopic composition implying an age of $\sim 3.3$. Ga for melt extraction (Peltonen \& Brügmann, 2006). The underlying deep layer (at $180-250 \mathrm{~km}$ depth) is the main source of Ti-rich pyropes of megacrystic composition, which however, lacks G10 pyropes. The osmium isotopic composition of the deep layer xenoliths is more radiogenic compared to middle layer. The deep layer is interpreted to represent a melt metasomatised equivalent of the Archean middle layer.

The mantle stratigraphy of the craton core, in the Kuhmo and Lentiira areas, shows less variation (O'Brien et al., 2003) and mantle stratification is absent. Most of the mantle column is similar to the middle layer at the Kaavi-Kuopio area showing a relatively homogenous distribution of harzburgite and lherzolite pyropes throughout. The overall magnesium number of the mantle lithosphere in this area is extremely high. Coupled with the rarity of mantlederived chrome diopside, the implication is that this portion of the mantle underwent unusually high levels of partial melting during the Archean

Fig. 3 (below). Simplified geological cross-section of the whole lithosphere along the 1000-km-long transect indicated on the map of Fig. 1.
2008) confirms the existence of depleted, and therefore ancient mantle underlying this area as well. Xenocryst pyrope chemistry demonstrates that lherzolite and harzburgite are roughly equally distributed down to depths of roughly $200 \mathrm{~km}$. We interpret the existence of harzburgite throughout the mantle section, without any obvious layering, to represent lithospheric mantle similar to that in the Kuhmo region, albeit slightly thinner.

Pyrope compositional distributions show that the Terskyi Bereg lithospheric mantle has a layered structure. At Terskyi a lherzolite-dominated upper mantle exists down to about $110 \mathrm{~km}$, and a harzburgitedominated middle layer exists from $110 \mathrm{~km}$ to about $150 \mathrm{~km}$. Sampling of the mantle deeper than this is extremely sparse, but the few data that exist suggest a roughly equal harzburgite - lherzolite mixture from 150 to $180 \mathrm{~km}$. The existence of abundant harzburgite is taken as evidence that this mantle is Archean in nature. Based on $m g$ of the pyropes, the composition of this mantle lies midway between that of the more fertile Kuopio-Kaavi mantle at craton edge and the depleted craton core mantle seen at Kuhmo-Kuusamo area (Zozulya et al., 2008).

Considerable chemical erosion of the mantle lithosphere has probably taken place within the Belomorian graben area between the Karelian and Kola-Kuloi cratons, since southern Kola mantle is considerably thinner (180 km at Terskyi Bereg) and the geotherm is elevated as compared to Karelia. Significant changes in SCLM characteristics also occurs across the White Sea strait between Kola and Kuloi cratonic blocks: in the central part of Zimnyi Bereg region (Lomonosov diamond mine, Arkhangelskaya pipe) lithospheric mantle again appears to be thick ( $>220 \mathrm{~km})$ and cool, and compositional layering is absent with Archean harzburgite throughout.

Svecofennian Orogen (c. $1.9 \mathrm{Ga}$ )

Karelia-Kola-Kuloi ( 3.5-2.6 Ga)

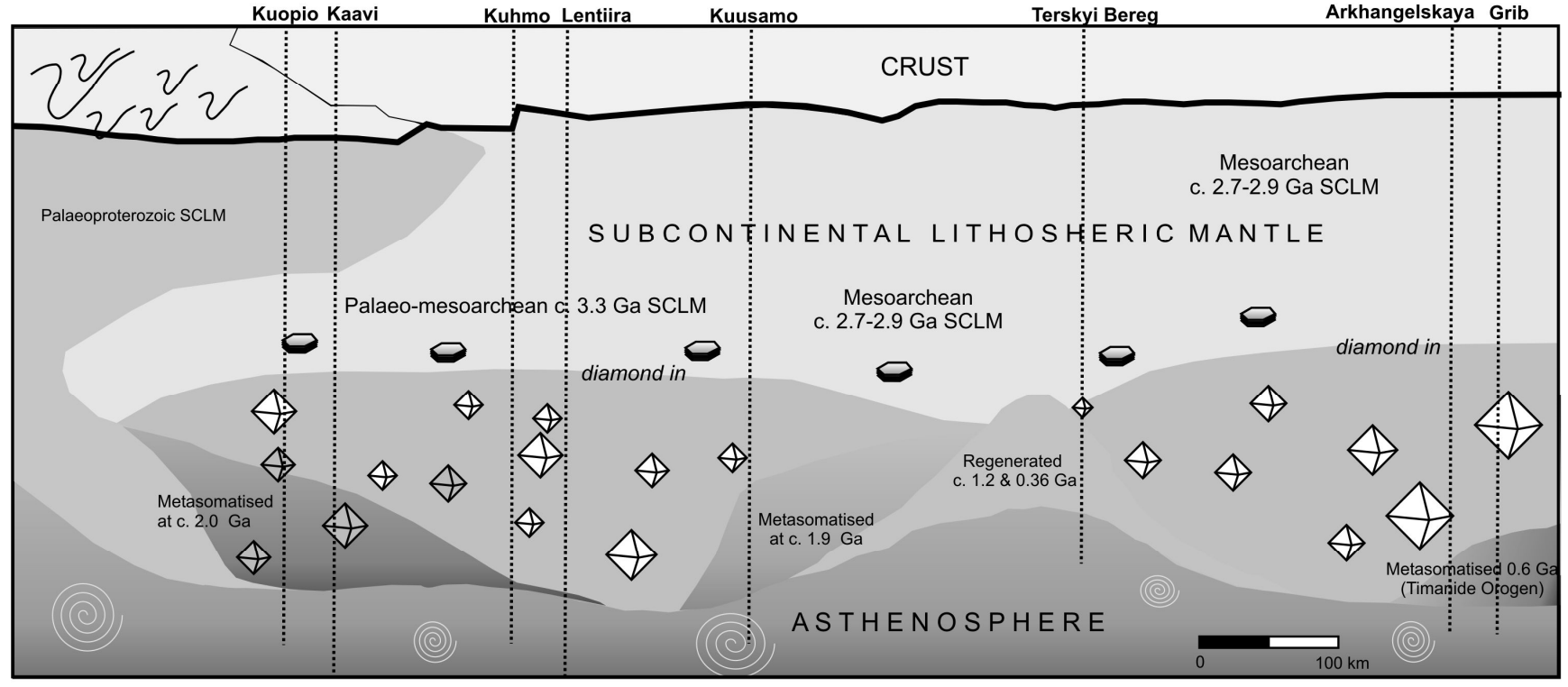

Vertical exaqaeration ca. 2:1 
For the Arkhangelskaya pipe chrome diopside xenocrysts yield a cool cratonic geotherm of ca. 36 $\mathrm{mW} / \mathrm{m}^{2}$ and indicate a sampling interval of $80-220$ $\mathrm{km}$ of the lithospheric mantle. The data indicate that a significant portion of this mantle contains diamondprospective depleted harzburgites, likely representing remnant Archean mantle. Eclogitic pyrope-almandine garnets are relatively abundant within the garnet population. Major element chemistry of Mg-ilmenite xenocrysts indicate that almost optimal redox conditions for diamond preservation, i.e. very low oxygen fugacity, prevailed in the mantle during the time of emplacement of the host kimberlite magmas. A significant proportion of the analysed chromites plot within the diamond stability field, suggesting that chromite-harzburgite is an important diamond host rock in the mantle underlying Zolotitskoye field (Lehtonen et al., 2008).

The pressure-temperature "window" where diamond is stable is up to $110 \mathrm{~km}$ thick (from 140 to $250 \mathrm{~km}$ ) in the core of the Karelian craton, but has been reduced to c. $40 \mathrm{~km}$ (from 140 to $180 \mathrm{~km}$ ) at both margins of the craton due to Proterozoic reworking of the deep lithosphere. Southern Kola (Terskyi) mantle lithosphere contains only a small segment within the diamond stability field, due to chemical erosion of the SCLM and the elevated geotherm at the vicinity to the Belomorian graben. On the SE side of the White Sea straits - in the Arkhangelsk region within the Kuloi cratonic block - the diamond window again expands to $100 \mathrm{~km}$ thick.

In summary, the subcontinental lithospheric mantle show considerable vertical and lateral heterogeneity across our 1000-km-long transect. The structure seems to be most complex within the Karelian CratonSvecofennian Orogen transition zone, where rifting and subsequent collisional events resulted in a layered mantle structure. A Proterozoic orogen also modified the mantle structure within the Karelia-Kola transition zone. More recently, several rifting (middle Riphean, Devonian-Carboniferous) and collisonal (Vendian Timan Orogen) events eroded and compositionally modified the deepest parts of the SCLM. The effects of these events to the diamond prospectivity are twofold: although they likely were destructive to peridotitic diamonds, they probably gave rise to younger generations of eclogitic diamonds in the lithospheric mantle.

\section{References}

Lehtonen, M., 2005. Rare-earth element characteristics of pyrope garnets from Kaavi-Kuopio kimberlites implications for mantle metasomatism. Bulletin of the Geological Society of Finland, 77, 31-47.

Lehtonen, M., O`Brien, H., Peltonen, P., Johanson, B., Pakkanen, L., 2004. Layered mantle at the Karelian Craton margin: $\mathrm{P}-\mathrm{T}$ of mantle xenocrysts and xenoliths from the Kaavi-Kuopio kimberlites, Finland. Lithos 77, 593-608.
Lehtonen, M., Kukkonen, I., O'Brien, H., Peltonen, P., Ustinov, V., Verzhak, V. 2008. Mantle signature of the Arkhan-gelskaya kimberlite pipe, NW Russia. $9^{\text {th }}$ International kimberlite conference, Frankfurt, Germany. Extended Abstract 00055.

Malkovets, V.G., Griffin, W.L., O’Reilly, S.Y., Wood, B.J., 2007. Diamond, subcalcic garnet, and mantle metasomatism: Kimberlite sampling patterns define the link. Geology 35, 339-342.

O`Brien, H.E., Bradley, J., 2008. New kimberlite discoveries in Kuusamo, northern Finland. $9^{\text {th }}$ Inter-national kimberlite conference, Frankfurt, Germany. Extended Abstract 00346.

O’Brien, H., Lehtonen, M., Spencer, R., Birnie, A., 2003. Lithospheric mantle in eastern Finland: a $250 \mathrm{~km} \mathrm{3D}$ transect. $8^{\text {th }}$ International Kimberlite Conference, Ext. Abst. FLA-0261, 5p.

Peltonen, P., Brügmann, G., 2006. Origin of layered continental mantle (Karelian craton, Finland): Geochemical and Re-Os isotope constraints. Lithos 89, 405-423.

Peltonen, P., Huhma. H., Tyni. M., Shimizu. N., 1999. Garnet peridotite xenoliths from kimberlites of Finland: Nature of the Continental mantle at an Archaean Craton Proterozoic mobile belt transition. In: Gurney, J.J. et al. (Eds.), Proceedings of the $7^{\text {th }}$ International Kim-berlite Conference, vol. 2, p. 664-676.

Peltonen, P., Kinnunen, K.A., Woodland, A.B., Seitz, H.-M., 2003. Origin of eclogites and diamonds in the Fennoscandian continental mantle. European Geophysical Society, Geophysical Research Abstracts, Vol. 5, 06728.

Ustinov, V., O’Brien, H., Lukianova, L., Peltonen, P. 2008a. Diamond-bearing kimberlites of northern Europe. $9^{\text {th }}$ International kimberlite conference, Frankfurt, Germany. Extended abstract 00112.

Zozulya, D.R., Peltonen, P., O'Brien, H., Lehtonen, M., 2008. Mantle derived minerals thermobarometry: lithosphere studies and diamond prospectivity of the Kola region (NW Russia). $9^{\text {th }}$ International kimberlite conference, Frankfurt, Germany. Extended abstract 00090 . 